\title{
The Profile of Horizontal and Vertical Mathematization Process of Junior High School Student with High Mathematical Ability in Solving Contextual Problem of Fraction
}

\author{
Muhammad Ahsanul Amala ${ }^{1}$, Rooselyna Ekawati ${ }^{2}$ \\ ${ }^{1}$ Pascasarjana Department of Mathematics, Universitas Negeri Surabaya, Indonesia, \\ muhammad.17070785002@mhs.unesa.ac.id \\ ${ }^{2}$ Pascasarjana Department of Mathematics, Universitas Negeri Surabaya, Indonesia, \\ rooselynaekawati@unesa.ac.id
}

\begin{abstract}
Knowing the mathematization process was important for teacher. In solving problem, students were using their mathematization process. This research aimed to describe the horizontal and vertical mathematization process of junior high school students with high mathematical ability in solving contextual problem of fraction. This research was descriptive qualitative research. The research subjects was determined by mathematical ability test (TKM). Thirty four students of chosen class were given mathematical ability test (TKM). Then, they were divided into three groups based on the ability which were high ability, medium ability, and low ability group. Researcher took one subject from high ability group to be research subject. Then, researcher gave the profile mathematization process test (TPPM). The semistructured interview was utilized to invstigate the answered of TPPM. The result of this research were: the high mathematical ability subject passed through all of activity in horizontal mathematization such as; identified the mathematical concept that is relevant to the problema; represented the problem in different ways; found the relations between problem language and the formal mathematic symbol; found the regularities, relations, pattern in problem; transfered the problem into mathematical model. The high mathematical ability subject also passed through all of activity in vertical mathematization such as; used the variety of different representation; used symbols, language, and formal mathematical process; made adjustments and development of mathematical models, combined, and united various models; created a mathematical argument; and generalized.
\end{abstract}

Keywords : mathematization process, fractions, contextual problem, mathematical ability

\section{Introduction}

Knowledge was something needed to all humanity. Knowledge was applied in daily life. Furthermore, one of the way to obtain knowledge was through education. In the knowledge dimension, junior high school students are formulated to have factual, 
conceptual, procedural, and metacognitive knowledge at a simple technical and specific level, so that students are able to associate that knowledge within themselves, their families, schools, communities, and the surrounding natural environment, nation, country and regional region [2].

Mathematization process was a process for mathematics phenomenon. Mathematics could be interpreted as a phenomenon mathematically model (in the sense of looking mathematics relevant to a phenomenon) or building a mathematical concept of a phenomenon [4]. [5] distinguished mathematization into two kinds, namely horizontal mathematization and vertical mathematization. [6] defines the horizontal mathematization was an activity changed contextual problems into mathematical problems (symbol), while the vertical was to formulate mathematization problems in a variety of settlement mathematics by using some the corresponding mathematical rules.

According [3] fraction was difficult materials for student in Indonesia. Fraction was one topics that must be mastered by students of 7 th grade [1]. A fraction is number that

can be represented by an ordered pair of whole numbers $\frac{a}{b}$ (or or $a / b$ ), where $b \neq 0[8,9]$. Fraction also can be defined as part of whole [10].

In solving mathematical problem, the students met their mathematization process. Thus, there were different way to solve the problem. Teacher have to know student mathematization process in order to choose the best model learning. So that, the goal of learning fraction would be achieved quickly. Student mathematization process could be identified by the profile mathematization process.

\section{Method}

This research aimed to describe the horizontal and vertical mathematization process of junior high school students with high mathematical ability in solving contextual problem of fraction. For this purpose, the researcher selected one student as the research subjects representing high mathematical ability. The type of research was descriptive qualitative research and used one contextual problem that was related of fraction. The research subjects was determined by mathematical ability test (TKM). The mathematical ability test (TKM) were adapted from the UN ( Ujian Nasional). TKM consisted of 10 essay problem. There were seven classes of 7th grade of SMPN 1 Tambakboyo, 7th G class was chosen purposively. Thirty four students of chosen class were given mathematical ability test (TKM). Then, they were divided into three groups based on the ability which were high ability group, medium ability group, and low ability group. The score of the test was arranged clearly based on [7]. Researcher took one subject from high ability group to be research subject. Then, researcher gave the profile mathematization process test (TPPM) to know the horizontal and vertical mathematization process. The semistructured interview was utilized to investigate the answered of TPPM. TKM and TPPM test were validated by the expert.

Data which was researcher got then to be analyze. The step to analyze the data in this research were described as follows.

- Transcripted the data: Data which was got from the interviewed were transcripted to the word or sentences.

- Categorized the data: Data were categorized based on the mathematical ability.

- Reducted the data: Unimportant data were reduced. Repeated and local language were deleted. This reduction data step was appropriate to the purpose of the research.

- Presented the data: The data from the previous step were presented. 
- Interpreted the data: The researcher interpreted the data based on horizontal and vertical mathematization process. Each horizontal and vertical mathematization process had the indicator.

- Made the conclusion: The researcher made the conclusion based on the data which was interpreted.

Table 1 describe the activity and indicator of horizontal and vertical mathematization process.

TABLE 1. The Activity and Indicator of Mathematization Process

\begin{tabular}{|c|c|c|}
\hline Step & Activity & Indicator \\
\hline \multirow[t]{6}{*}{$\begin{array}{l}\text { 1. Horizontal } \\
\text { Mathematization }\end{array}$} & $\begin{array}{l}\text { - Identified the } \\
\text { mathematical concept } \\
\text { that was relevant to the } \\
\text { problem }\end{array}$ & $\begin{array}{l}\text { Student said the concept } \\
\text { to solve the problem }\end{array}$ \\
\hline & $\begin{array}{l}\text { - Represented the problem } \\
\text { in different ways }\end{array}$ & $\begin{array}{l}\text { - Student said the problem } \\
\text { with her own words } \\
\text { (formulating) }\end{array}$ \\
\hline & & $\begin{array}{l}\text { - Student visualized the } \\
\text { problem by drawing }\end{array}$ \\
\hline & 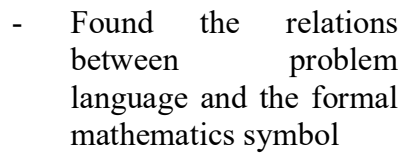 & $\begin{array}{l}\text { - Student connected the } \\
\text { word in the problem with } \\
\text { mathematics symbol }\end{array}$ \\
\hline & $\begin{array}{l}\text { - Found the regularities, } \\
\text { relations, pattern in } \\
\text { problem }\end{array}$ & $\begin{array}{l}\text { - Student found the pattern } \\
\text { to solve the problem }\end{array}$ \\
\hline & $\begin{array}{l}\text { - Transfered the problem } \\
\text { into mathematical model }\end{array}$ & $\begin{array}{l}\text { Student used } \\
\text { mathematical model to } \\
\text { solve the problem easily }\end{array}$ \\
\hline \multirow[t]{5}{*}{$\begin{array}{l}\text { 2. Vertical } \\
\text { Mathematization }\end{array}$} & $\begin{array}{l}\text { - Used the variety of } \\
\text { different representation }\end{array}$ & $\begin{array}{l}\text { - Student used the } \\
\text { different representation } \\
\text { which related to the } \\
\text { problem }\end{array}$ \\
\hline & $\begin{array}{l}\text { Used the symbols, } \\
\text { language, and formal } \\
\text { mathematical process }\end{array}$ & $\begin{array}{l}\text { - Student used the form } \\
\text { and the operation of } \\
\text { mathematics }\end{array}$ \\
\hline & $\begin{array}{l}\text { Made adjustments and } \\
\text { development } \\
\text { mathematical models, } \\
\text { combined, and united } \\
\text { various models }\end{array}$ & $\begin{array}{l}\text { - Student revised the } \\
\text { picture that she made }\end{array}$ \\
\hline & $\begin{array}{l}\text { - Created a mathematical } \\
\text { argument }\end{array}$ & $\begin{array}{l}\text { - Student give feedback } \\
\text { and reason in solving } \\
\text { problem }\end{array}$ \\
\hline & - $\quad$ Generalized & $\begin{array}{l}\text { - Student applied the same } \\
\text { way to solve another } \\
\text { problem }\end{array}$ \\
\hline
\end{tabular}

\section{Result and Discussion}

Before doing the TPPM test the student were given the mathematical ability test TKM. Thirty-four student of chosen class doing the TKM test. In this table was the result of TKM test of the class. 
The Profile of Horizontal and Vertical Mathematization Process of Junior High School Student with High Mathematical Ability in Solving Contextual Problem of Fraction

TABEL 2 The Result of mathematical ability test (TKM) of VII G SMPN 1 Tambakboyo

\begin{tabular}{|c|c|c|}
\hline No. & Name & Score \\
\hline 1. & ATT & 97 \\
\hline 2. & SA & 88 \\
\hline 3. & $\mathrm{RF}$ & 88 \\
\hline 4. & SFN & 84 \\
\hline 5. & $\mathrm{AP}$ & 82 \\
\hline 6. & MFP & 80 \\
\hline 7. & MSA & 78 \\
\hline 8. & DFM & 78 \\
\hline 9. & $\mathrm{ZF}$ & 78 \\
\hline 10. & WDR & 78 \\
\hline 11. & FSA & 78 \\
\hline 12. & $\mathrm{BM}$ & 75 \\
\hline 13. & AS & 75 \\
\hline 14. & RSA & 71 \\
\hline 15. & MLA & 71 \\
\hline 16. & SRP & 69 \\
\hline 17. & MSA & 69 \\
\hline 18. & S & 67 \\
\hline 19. & RU & 67 \\
\hline 20. & ANK & 65 \\
\hline 21. & SKN & 63 \\
\hline 22. & $\mathrm{AK}$ & 61 \\
\hline 23. & TNA & 59 \\
\hline 24. & RVN & 59 \\
\hline 25. & $\mathrm{FL}$ & 55 \\
\hline 26. & ADP & 53 \\
\hline 27. & $\mathrm{BN}$ & 53 \\
\hline 28. & HNK & 51 \\
\hline 29. & MAA & 51 \\
\hline 30. & MAR & 51 \\
\hline 31. & AAA & 47 \\
\hline 32. & DA & 47 \\
\hline 33. & $\mathrm{IJ}$ & 47 \\
\hline 34. & MB & 47 \\
\hline
\end{tabular}

Based on [3] the result was divided into three group of mathematical ability. There were high mathematical ability, medium mathematical ability, and low mathematical ability. In the high mathematical ability group, one student namely ATT were chosen as research subject and then given TPPM test. 
After doing the TPPM test, the result must be classified to the mathematization process. There were two mathematization process : horizontal mathematization process and vertical mathematization process.

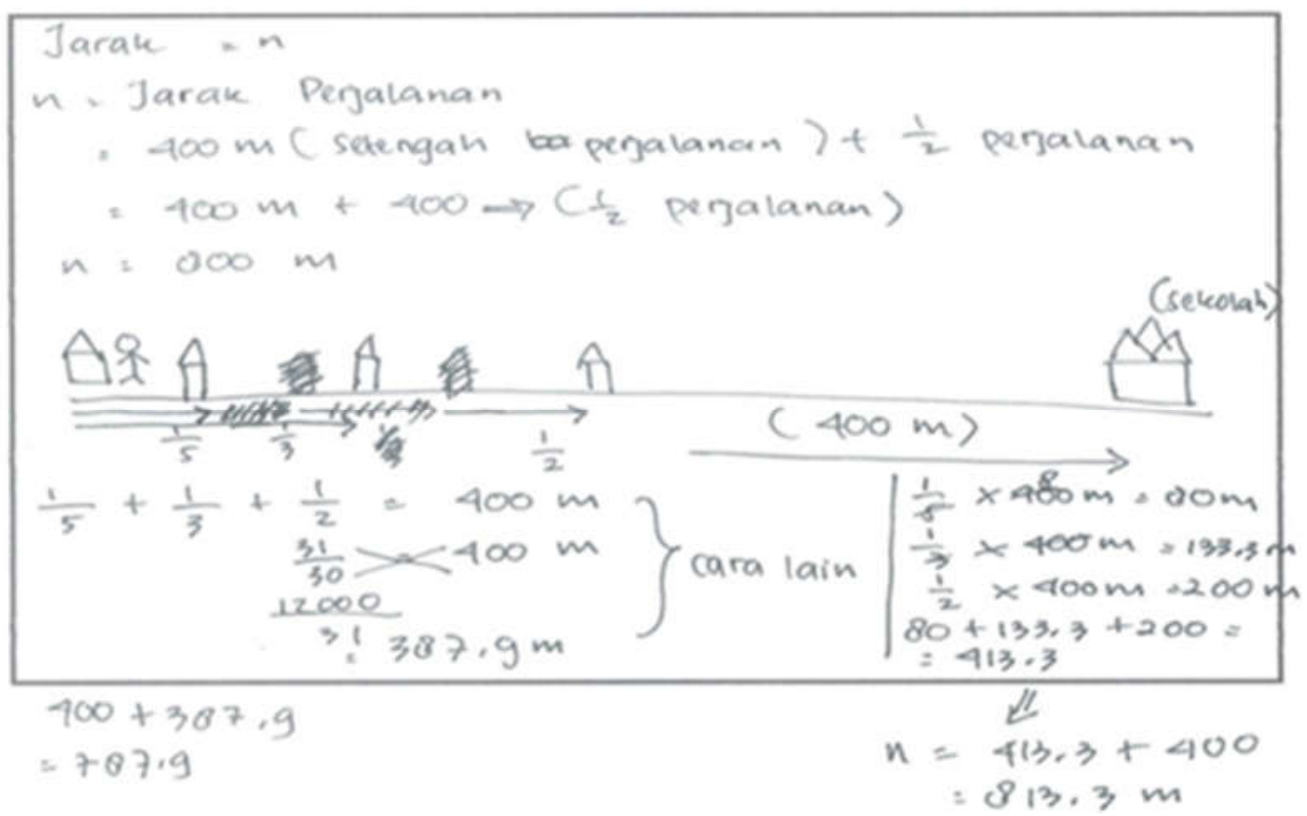

Figure 1. The student's answer of the profile mathematization process test (TPPM)

\subsection{Horizontal Mathematization Process}

Based on the student's answer of the profile mathematization process test (TPPM), the horizontal mathematization process could be known. But for making it sure, the above answer was justified with the result of the interview as follows.

Q : What did you think about the problems?

$\mathrm{S}$ : Should sum the one fifth, one third, a half in meters and added all of them.

Q : What did mathematics concept use to solve the problems?

$\mathrm{S}$ : Fraction. Addition and multiplication.

Q : What did you know about the problems?

$\mathrm{S}$ : Joni went to school. He through the fashion store, then through bakery, and stop at electronic store.

Q : The $\frac{1}{2}$ where did it come from?

$\mathrm{S}:$ In a half way distance

Q : Why did you draw the picture? It was related to the problem, wasn't it?

$\mathrm{S}$ : Yes, because it helped me to solve problem. a half, one fifth, one third (pointed the picture)

Q : So, What the distance between Joni's house and his school?

S : $\frac{1}{5} \times 400=80 \mathrm{~m}, \frac{1}{3} \times 400=133,3 \mathrm{~m}$, dan $\frac{1}{2} \times 400=200 \mathrm{~m}$.

Based on the student's answer and the interview, the horizontal mathematization process of student with high mathematical ability could be known as follows.

- Identified the mathematical concept that was relevant to the problem 
Student said the fraction concept and using addition to solve the problem. This was known by the student's response when the researcher give the question "What did mathematics concept use to solve the problem?" the student answer "Fraction. Addition and multiplication".

- Represented the problem in different ways Student said the problem with her own words (formulating) and visualized the problem by drawing. This was known by the student's answered in the TPPM.

- Found the relations between problem language and the formal mathematic symbol

Student wrote $\frac{1}{2}$ for the word "half" in the problem. This was known by the student's answered in TPPM.

- Found the regularities, relations, pattern in problem

While the student was interviewed, the student pointed the distance half way, one third, and one fifth from the picture that she made.

- Transferred the problem into mathematical model Student wrote $\frac{1}{2} \times 400=80 \mathrm{~m}, \frac{1}{3} \times 400=133,3 \mathrm{~m}$, dan $\frac{1}{2} \times 400=200 \mathrm{~m}$. Then add all the results. This was known by the student's answered in TPPM.

\subsection{Vertical Mathematization}

Furthermore, vertical mathematization process could be identified by student's answer of the profile mathematization process test (TPPM). To justify the answer, the interview must be done as follows.

Q : What was the " $n$ " in your answer?

$\mathrm{S}$ : The symbol of the distance. The distance of the house and the school was " $n$ "

Q : How many fraction form in the problems?

$\mathrm{S}$ : There were three fraction forms.

Q : Why did you change your own figure? Why did you draw again?

$\mathrm{S}$ : Because, I thought the figure wasn't related with the problems, so that must be changed.

Q : Your answer was a half, how did it come from?

$\mathrm{S}$ : By adding one fifth and two over fifteen then the result added by one sixth

Q : Why did you add all of the result of fraction form?

$\mathrm{S}$ : Because the question was to determine the distance, so it must be added all of the result.

Q : So, How did you get $\frac{1}{2}$ as your result?

$\mathrm{S}: \frac{1}{5}$ plus $\frac{2}{15}$ plus $\frac{1}{6}$

Q : What was $\frac{1}{2}$ of your result?

$\mathrm{S}$ : The distance from Joni's house to electronic store

Q : Was Joni's activities related to your daily activity?

$\mathrm{S}$ : Yes, I was. I went to school on walk.

Q : So, could you count the distance from your home to your school?

$\mathrm{S}$ : Yes, I could count the distance. 


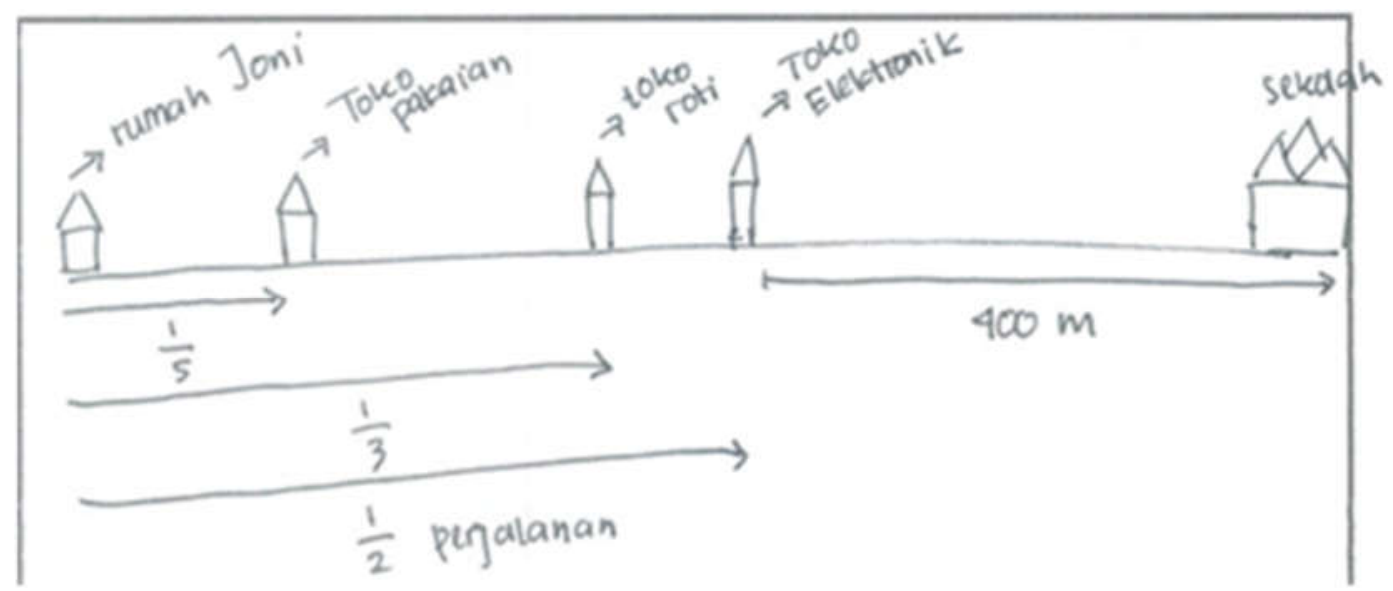

Figure 2. The extended student's answer of the profile mathematization process test (TPPM)

Based on the student's answer and the interview, the vertical mathematization process of student with high mathematical ability could be known as follows.

- Used the variety of different representation

Student wrote " $n$ " for the distance between Joni's house and his school. This was known by the student's answered. The interviewed also show the students response when the researcher give the question "What was the " $n$ " in your answer?" then she answered "The symbol of the distance. The distance of the house and the school was n". Student also wrote $\frac{1}{2}$ for half way. This was known by the student's answered.

- Used the symbols, language, and formal mathematical process

Student used the fraction form such as $\frac{1}{2}, \frac{1}{5}, \frac{1}{3}$ and the operation (addition and multiplication) to solve the problem. This was known by the student's answered in the TPPM.

- Made adjustments and development of mathematical models, combined, and united various models

Student was known that figure which she made before was incorrect. Then she made adjustment to the figure (draw the new figure that was relevant with the problem). This was known by the student's answered in TPPM. In the interviewed also known while the researcher give the question "Why did you change your own figure? Why did you draw again?" then the student answered "Because, I thought the figure wasn't related with the problems, so that must be changed".

- Created a mathematical argument

Student give feedback and reason in solving problem. The first feedback and reason was appeared while the researcher give the student question "Your answer was a half, how did it come from? "then the student answered "By adding one fifth and two over fifteen then the result added by one sixth". The second feedback and reason was appeared while the researcher give the student question "Why did you add all of the result of fraction form?" then the student answered "Because the question was to determine the distance, so it must be added all of the result".

- Generalized

Student applied the same way to solve another problem. This was known by the student's response when the researcher gives the question "Was Joni's activities related to your daily activity?" then student answered "Yes, I was. I went to school on walk". 
The Profile of Horizontal and Vertical Mathematization Process of Junior High School Student with High Mathematical Ability in Solving Contextual Problem of Fraction

The researcher gives the next question "So, could you count the distance from your home to your school?" then student answered "Yes, I could count the distance".

In this table below showed the summary of the mathematization process of student with high mathematical ability in solving problem and interviewing.

TABLE 2. Mathematization Process of Student with High Mathematical Ability.

\begin{tabular}{|c|c|c|}
\hline Step & $\begin{array}{c}\text { Activity } \\
\end{array}$ & Indicator \\
\hline \multirow[t]{6}{*}{$\begin{array}{l}\text { 1. Horizontal } \\
\text { Mathematization }\end{array}$} & $\begin{array}{l}\text { - Identified the mathematical } \\
\text { concept that was relevant to } \\
\text { the problem }\end{array}$ & $\begin{array}{l}\text { - Student said the fraction concept } \\
\text { and using addition to solve the } \\
\text { problem }\end{array}$ \\
\hline & $\begin{array}{l}\text { - Represented the problem in } \\
\text { different ways }\end{array}$ & $\begin{array}{l}\text { - Student said the problem with her } \\
\text { own words (formulating) }\end{array}$ \\
\hline & & $\begin{array}{l}\text { - Student visualized the problem } \\
\text { by drawing }\end{array}$ \\
\hline & $\begin{array}{l}\text { - Found the relations between } \\
\text { problem language and the } \\
\text { formal mathematic symbol }\end{array}$ & $\begin{array}{l}\text { - Student wrote } \frac{1}{2} \text { for the word } \\
\text { "half" in the problem }\end{array}$ \\
\hline & $\begin{array}{l}\text { Found the regularities, } \\
\text { relations, pattern in problem }\end{array}$ & $\begin{array}{l}\text { - Student pointed the distance half } \\
\text { way from the picture that she } \\
\text { made }\end{array}$ \\
\hline & $\begin{array}{l}\text { - Transferred the problem into } \\
\text { mathematical model }\end{array}$ & $\begin{array}{l}\text { - } \text { Student wrote } \frac{1}{5} \times 400=80 \mathrm{~m}, \frac{1}{3} \times \\
400=133,3 \mathrm{~m} \text {, dan } \frac{1}{2} \times 400= \\
200 \mathrm{~m} . \text { Then add all the results. }\end{array}$ \\
\hline \multirow[t]{6}{*}{$\begin{array}{l}\text { 2. Vertical } \\
\text { Mathematization }\end{array}$} & $\begin{array}{l}\text { Used the variety of different } \\
\text { representation }\end{array}$ & $\begin{array}{l}\text { - Student wrote " } n \text { " for the distance } \\
\text { between Joni's house and his } \\
\text { school }\end{array}$ \\
\hline & & - Student also wrote $\frac{1}{2}$ for half way \\
\hline & $\begin{array}{l}\text { - Used the symbols, language, } \\
\text { and formal mathematical } \\
\text { process }\end{array}$ & $\begin{array}{l}\text { - Student used the fraction form } \\
\text { and the operation to solve the } \\
\text { problem }\end{array}$ \\
\hline & $\begin{array}{l}\text { Made adjustments and } \\
\text { development of mathematical } \\
\text { models, combined, and united } \\
\text { various models }\end{array}$ & $\begin{array}{l}\text { - Student revised the picture } \\
\text { because she knew the picture was } \\
\text { not appropriate with the problem }\end{array}$ \\
\hline & $\begin{array}{l}\text { Created a mathematical } \\
\text { argument }\end{array}$ & $\begin{array}{l}\text { - Student give feedback and reason } \\
\text { in solving problem }\end{array}$ \\
\hline & - $\quad$ Generalized & $\begin{array}{l}\text { - Student applied the same way to } \\
\text { solve another problem }\end{array}$ \\
\hline
\end{tabular}

\section{Conclusion}

Based on the result and discussion, the researcher concluded the horizontal and vertical mathematization process of the junior high school student with high mathematical ability in solving contextual problem of fraction. 
The conclusion of this research were: the high mathematical ability subject passed through all of activity in horizontal mathematization such as; identified the mathematical concept that is relevant to the problema; represented the problem in different ways; found the relations between problem language and the formal mathematic symbol; found the regularities, relations, pattern in problem; transfered the problem into mathematical model. The high mathematical ability subject also passed through all of activity in vertical mathematization such as; used the variety of different representation; used symbols, language, and formal mathematical process; made adjustments and development of mathematical models, combined, and united various models; created a mathematical argument; and generalized.

\section{Acknowledgements}

This research reported herein was supported by SMPN 1 Tambakboyo.

\section{References}

[1] The Indonesian Ministry of Education and Culture, Regulations of the Ministries of Education and Culture Number 24, Jakarta: State Secretariat, 2016

[2] The Indonesian Ministry of Education and Culture, Regulations of the Ministries of Education and Culture Number 20, Jakarta: State Secretariat, 2016

[3] M. Ridwan, "Peningkatan Hasil Belajar Membandingkan Pecahan Menggunakan Media Garis Bilangan Limbah Triplek pada Siswa Kelas 3 SDN Batok 01 Kecamatan Gemarang Kabupaten Madiun”, Indonesian Digital Journal of Mathematics and Education, vol. 2, no. 3, 2015, 134 - 143

[4] A. Treffers, Three Dimensions A Model Of Goal And Theory Description In Mathematics Education, Dordrecht: Reidel The Wiscobas Project, 1987

[5] H. Frudenthal, Revisiting Mathematics Education China Lectures, Dordrecht: Kluwer, 2002

[6] J. R. Murdani and Turmudi, "Pengembangan Perangkat Pembelajaran Matematika dengan Pendekatan Realistik untuk Meningkatkan Penalaran Geometri Spasial Siswa di SMP Negeri Arun Lhokseumawe", Jurnal Peluang (Banda Aceh) vol. 1 no. 2, 2013, 22-32

[7] T. G. Ratumanan, and T. Laurens, Evaluasi hasil belajar yang relevan dengan kurikulum berbasis kompetensi, Surabaya : Unesa press, 2003

[8] G. L. Musser, B. E. Peterson and B. F. Burger, Mathematics for Elementary Teachers: A Contemporary Approach, New Jersey: Willey, 2013

[9] H. Wu, Fraction, Barkeley: University of California, 2012

[10] J. A. V. D. Walle, K. S. Karp and J. M. Bay-Williams, Elementary and Middle School Mathematics, New Jersey: Pearson, 2013 